\title{
Introduction
}

\section{Libya: Lost in Transition}

\author{
Jacob Mundy \\ Associate Professor of Peace and Conflict Studies and Middle Eastern and \\ Islamic Studies, Colgate University, Hamilton, NY, USA \\ jmundy@colgate.edu
}

The guiding concept for this special journal section is to explore the increasing normalization of Libya's post-2011 "transition" and its reification into a new social, juridical and economic status quo. Amid constant news reports and think tank analyses of chaotic armed conflict, political fragmentation, and even wholesale "state failure," we wanted to highlight the extent to which this protracted interregnum - between the collapse of Mu'ammar al-Gaddafi's decrepit Jamahiriyyah system in 2011 and the failure of any political coalition to achieve a new hegemonic order since then - can no longer be considered just that, an interregnum.

So what is Libya's new normal, and how do the contributions here attempt to account for it? In the wake of the 2011 uprisings across Northern Africa and Southwest Asia, it has become commonplace to invoke Gramsci's now famous theorization of crisis from the Prison Notebooks as historical moments in which the old order can no longer be sustained but whose replacement cannot be established either. In the case of Libya, the crisis results from the entanglement of these two processes, and, in many ways, it has come to represent the new order itself. This is precisely where we can situate Emad Badi's contribution to this collection. On the one hand, he historically situates Libya's recent decade of "morbid symptoms" - to continue to invoke Gramsci-in the structures and tactics of rule that marked the Gaddafi regime's centralized forty-two year grip on power (1969-2011). On the other hand, he also evaluates European theories of the state against these historical and contemporary realities. He finds them unable to account for the forms of order and disorder, and the ways in which governmental forms are established and challenged, in the Libyan context. 
Pace James Scott, it is not only the peasants, the proletariat, or the general citizenry that seek to evade (or manipulate) those in power; sometimes those with power find as much advantage in evading the very states they create and lead. These latter tendencies are not only one of the most important political inheritances from the Jamahiriyyah system, but they are also key to seeing through the cloud of obfuscations that paint Libya as simply a failed state.

With this historical and counter-theoretical background in mind, questions then arise as to the reproduction of Libya's permanent interregnum. Much debate has circulated as to the decisive political cleavages that increasingly destabilized the post-Gaddafi regime and eventually shattered it in 2014. Perhaps the grossest yet most widely adopted oversimplification has been that of so-called Islamists versus secularists, a simplification that quickly crumbles once an analysis of religious legitimation and mobilization is applied to all of the main political and armed actors. Focusing on one particular coalition in Libya's civil war, the Muslim Brotherhood, Haala Hweio chooses instead to examine the organization as a conglomeration of social, political, and economic interests that are embedded not only within an "internal" context of often violent contention but also as part of international and transnational dynamics, above all the repressive restoration of military authoritarianism in Egypt vis-à-vis the political dispossession of the Egyptian Brotherhood's short-lived government. In blurring the lines between the domestic and the international, Hweio draws our attention to the broader set of forces that have led to the destabilization of Libya and that extend well beyond national boundaries. Though it is more common in recent months and years to recognize the extent to which Libya's civil war has been internationalized by covert and overt forms of outside military intervention from the very beginning of Libya's transition in 2011, Hweio examines the ways in which Libya was from the start being interpellated by forces and powers that would radically alter Libya's geopolitical and global economic positionality, and thus make it vulnerable to contingencies well beyond its control (e.g., the 2013 military coup in Egypt). Though the inheritance and reproduction of social divisions and a weak central government factor into Hweio's analysis, she convincingly demonstrates that analyses of Libya's conflicts, particularly from 2014 onward, that fetishize endogenous factors will fail to account for the actual forces at play.

At the same time, it should also be recognized that the nature of Libya's social, political, and economic dynamics since 2011 has created the conditions for a wide variety of new actors, coalitions, and ideologies to emerge and evolve. Generally speaking, Libya's revolutionary militias-the armed groups that fought in the 2011 civil war against the old regime-have received the most attention in this respect, particularly as the main catalyst of the 2014 civil 
war, as conduits for foreign influence, and as entrepreneurs in the new war economy. The role of militias in post-revolutionary Libya is perhaps overdetermined, and the obsessive focus upon them has often obfuscated the emergence of other new social formations and actor classes in Libya since 2011. Focusing on "revolutionary" Libyan youth who do the exact opposite of the militias and work with foreign aid agencies on issues of development and peacebuilding, Chiara Loschi documents through extensive interviews the development—and disillusionment - of this new class of postconflict experts. Acting as critical liaisons between risk-averse international organizations and Libya's civil society groups, these highly educated former revolutionary activists have experienced, and been participants in, the reification of the very transition that their labors intended to overcome. Through their words, we see James Ferguson's anti-politics machine in action in Libya: foreign organizations with political mandates and large budgets to "do something" in Libya concoct developmental and peacebuilding schemes from their safe offices in Tunis while relying on their Libyan "counterparts" who often take great personal risks to implement programs on the ground with little oversight, accountability, or assessment. In the absence of any way to effect meaningful change, these new indigenous experts, though weary of becoming a comprador class for the international peacebuilding and development industries, find little hope except in their career formation and advancement. It is not lost on them that they have ironically become an element of Libya's post-2011 professional managerial classes whose very expertise is the interregnum in which they, along with many others, have become stakeholders. 